\title{
A Form of Conservation and Inheritance for Ceremonial Dance in
}

\section{Ancient Ruins of Southern Isan}

\author{
Manutsawee Srirachlao ${ }^{1}$, Patamawadee Chansuwan ${ }^{2} \&$ Urarom Jantamala ${ }^{2}$
}

${ }^{1}$ The Faculty of Cultural Science, Mahasarakham University, Khamriang Sub-District, Kantarawichai District, Maha Sarakham Province, Thailand

${ }^{2}$ Faculty of Fine Arts, Mahasarakham University, Maha Sarakham Province, Thailand

Correspondence: Manutsawee Srirachlao, 71 Moo 13, Kaeng Loeng Chan Sub-district, Mueang District, Maha Sarakham, 44000, Thailand. E-mail: manutsawee242@hotmail.com

Received: March 20, 2013 Accepted: April 18, 2013 Online Published: June 1, 2013

doi:10.5539/ass.v9n7p200 URL: http://dx.doi.org/10.5539/ass.v9n7p200

\begin{abstract}
Ceremonial dance in ancient ruins of southern Isan is a part of culture that has been visible in Thailand since antiquity. Despite changes to the social and cultural landscape of the nation, ceremonial dance has been preserved, although the latest waves of modernity are threatening to destroy the art form. It is now vitally important for local communities to conserve and pass on knowledge of their rituals and customs to future generations. This qualitative research examines the background and current conditions of ceremonial dance culture in order to suggest a model for future preservation, which can be employed by local communities to prevent the disappearance of this ancient art.
\end{abstract}

Keywords: conservation, inheritance, ceremonial dance, southern Isan, ancient, worship

\section{Introduction}

Culture is a necessity of human life that helps humanity and society to higher development by having no end. However, this path to higher development is dependent upon the ability of humans to improve or create appropriate new culture. If the culture is particularly suitable, the society will be able to prosper commensurately. Suitability of culture is the creation of benefits for everyday life in the society (Lengbracha, 1990: 19). Therefore, culture will reflect the quality of people's lives, as well as the art and culture of the local community, according to the regions of Thailand.

The Isan Region, or the Northeastern Region of Thailand, is a large, wide area of many settlements and makes up one third of the land area of the country. There are twenty provinces in the region, which consist of Nakhon Ratchasima, Khon Kaen, Chaiyaphum, Buriram, Yasothon, Surin, Sisaket, Roi Et, Maha Sarakham, Loei, Sakon Nakhon, Nong Khai, Nongbua Lamphu, Udon Thani, Mukdahan, Ubon Ratchathani, Amnat Charoen, Nakhon Phanom, Kalasin and Bueng Kan. Nowadays, the Northeastern Region is developing and promoting tourism in government districts, especially in the lower areas, such as Nakhon Ratchasima, Buriram, Surin and Sisaket. The prominent features in these areas are ancient stone ruins, specifically of Prasat, or ancient temples, which represent the artistic culture of the locality and country. These areas are worth conserving and restoring because they provide cumulative evidence of knowledge, meaning and value of culture from the past until the present. This information can be learnt by future generations in order to make them understand their origins and instill Thai national pride (Tourism Authority of Thailand, 2011:3).

Ancient ruins represent the stories of and pride in the human past, which bring about conscious mental awakening to their own conservation by revealing concepts and methods of practices employed from the past to the present. Various Thai theories concerning the preservation of ancient ruins are found in historical documents, inscriptions and assorted chronicles (Suksawat, 1994: 157). Currently, important ancient ruins are places of faith and worship of the people, who host various ceremonies and rituals in order to show their unconditional belief in these sacred relics. Aside from this, the sites are cultural tourist attractions that give additional value to these ceremonies and transform them into local culture. One such example is the Phimai Tourism Festival in Nakhon Ratchasima. At this festival there are light and sound performances to tell the legend of Vimay Natakan and the act Niramitkam Nuea Lam Nam Mun, which is a story told by dance that was adapted from images and deep, precise study of the period of Emperor Jayavarman VII. The performance is extremely famous and is held annually from the thirteenth to the fifteenth of November in the Phimai Historical Park, Phimai District, Nakhon 
Ratchasima Province. In Buriram Province, a festival is organized in the sacred month of Phanom Rung, which runs from the fifth of March until the fourth of April. This festival is to publicize the importance of Prasat Phanom Rung in order to promote tourism in the temple city. The prominent characteristics to attract the interest of visiting tourists are rituals to give offerings to the sacred relics in the Phanom Rung Historical Park, rituals to give offerings to Pra Jao Prasat Thong and the ritual to offer eight lotus petals to the universal centre of Shiva Lingam, which is a representation of the Hindu deity Shiva, and a sacred relic on Prasat Phanom Rung. Surin Province organizes the 'Inheritance of the One Thousand Year Legend of Prasat Sikhoraphum', during which there is a carnival procession of Khmer, Laos, Kuay and Chinese cultures, a ritual to give offerings to Prasat Sikhoraphum and an acting performance, including color, light and sound shows to tell the story of the 'Inheritance of the One Thousand Year Legend of Prasat Sikhoraphum' and the act Kasintara Maha Natakam Dam Nan Pan Bi Saiwa Mani Sikhoraphum. Sisaket Province holds the festival entitled 'Recollection of Prasat Sa Kamphaeng Yai on the second day of the waxing moon in the fifth month of Wissuwa Songkran'. Activities at Prasat Sa Kamphaeng Yai during the festival include rituals to give offerings to Prasat Sa Kamphaeng Yai, seven Sriphrutthesuan carnival processions, an acting, color, light and sound show to tell the story Sirawatri Haeng Sriphrutthesuan, evening meals, the Miss Sriphrutthesuan Beauty Contest and Buddhist prayer song recital competitions (Tourism Authority of Thailand, 1999: 28-9). The organization of religious ceremonies, the promotion of local wisdom related to religious ceremonies and restoration and conservation are achieved by holding ceremonies that represent the beliefs and faith of the local residents. When holding a religious ceremony, the actual practices in the local community and the Buddhist, Brahman or Hindu religions are to be followed, especially during sacred festivals. Tourists visiting outside holy festivals miss the opportunity to experience the ceremonies. In light of this, the lengthening of festival durations would better accommodate locals and visiting tourists, enabling them to participate in religious ceremonies according to their belief at every suitable opportunity. Regarding the organization of rituals and traditions at the various ancient temples, the one imperative feature is ceremonial dancing. These are performances by students, youth and the local community that retell the history and form of ancient Khmer rituals for the benefit of domestic and foreign tourists so to improve their knowledge of ancient ruins in national historical parks. The prominent feature that attracts the interest of the tourists is the ritual of making offerings to spirits, especially ceremonial dance, which not only offers insight into sacred customs, but also highlights the local identity from the architectural and sculptural symbols visible on the ancient temples. The reason for this is that the procedures of each dance at each ancient temple are designed from the evidence available at and on the archaeological sites of the temples, in addition to local beliefs.

In order to adapting histories, sculptures, paintings, carvings and archaeological evidence to dancing postures, the creators or designers must know and understand the key principles of the creation without using misconceptions or preconceived ideas. Several experts created performing projects in this manner, such as Lamun Yamakhup and Chaloei Sukhawanit, who, after studying ancient remains and historical objects, were able to create many performances. These performances include Ra Bam Lop Buri, which was created from the idea and model of Phra Prang Sam Yot, Lop Buri Province, and Ra Bam Sukhothai, which was created from the ideas and models of dancing in the sculptures of Sukhothai Province (Sunthranon, 2005: 16-19).

As a result of the historical information that has been concretely researched and arranged by historians and archaeologists in the form of documents, essays, current academic work, in addition to the theories, beliefs and customs of local Thai people, concepts of ceremonial dance have been created in order to reflect the identity of the local people in areas of ancient ruins, to coexist with other dances and to gain popularity as a part of the ritual of offering in the festivals that have been inherited until today.

Ceremonial dancing performances not only play important roles in worshipping ancient ruins but also act as instruments for perpetuating folk culture and history through dancing postures and melodies, including costumes, which are adapted from models in carvings or sculptures found in the ruins. Thai dancing performances created by famous experts promote national culture and arts in both direct and indirect ways. Directly, they play important roles as relationship media between Thailand and other countries. Indirectly, they are integrated into religious ceremonies and folk traditions or social activities so that members of the community appreciate their value and perpetuate them as part of the community cultural heritage.

Apart from reflecting belief, theories and customs of the locality that have been inherited over time, research into ceremonial dance in ancient stone ruins also aids inheritance, conservation and promotion of valuable culture. Ceremonial dance remains a symbol associated with connecting belief and faith of the people and the ancient ruins. It is also a part of the festivals that promote conservational tourism in response to the governmental policy of national tourism. The researchers were thus interested in ceremonial dance creation in ancient ruins in order to 
conserve and inherit dance culture, so as to permanently maintain its value in the community, without it being lost to current culture and modern society. The researchers also saw the need to promote dance-related tourism and the value of its place in culture in order to ensure its part in future national heritage.

\section{Research Objectives}

This research had three research objectives: a) to study the historical background of ceremonial dance in ancient ruins of southern Isan; b) to study the current conditions of and problems with ceremonial dance in ancient ruins of southern Isan; c) to study a form of conservation and inheritance for ceremonial dance in ancient ruins of southern Isan.

\section{Research Methodology}

This research, a form of conservation and inheritance for ceremonial dance in ancient ruins of southern Isan, used a cultural qualitative research method in order to promote the body of knowledge surrounding the historical background of the topic, including beliefs, customs and rituals. The method was also used to investigate the current conditions of and problems with ceremonial dance in ancient ruins of southern Isan and study a form of conservation and inheritance for ceremonial dance in ancient ruins of southern Isan. The researchers obtained and analyzed data from document and field research. The research tools used were survey, interview, observation and focus group discussion. The research area of four provinces, Nakhon Ratchasima, Surin, Buriram and Sisaket, were selected based on three criteria. The first requirement was an ancient ruin; the second requirement was for a ruin holding rituals of offering and ceremonial dance; the final requirement was an ancient ruin promoting cultural value. From these three criteria, the researchers identified Prasat Hin Phimai in Nakhon Ratchasima Province, Prasat Kha Phanom Rung in Buriram Province, Prasat Sikhoraphum in Surin Province and Prasat Wat Sa Kamphaeng Yai in Sisaket Province.

Data analysis for this research was achieved by studying the information gathered from related research documents, observation, interview and focus group discussion. The data was analyzed according to the research objectives by using the concepts and theories concerned as the instruments for examining and describing each research purpose. The findings and conclusions are here presented as a descriptive analysis.

\section{Research Results}

The results of the study of a form of conservation and inheritance for ceremonial dance in ancient ruins of southern Isan are here presented according to the three research objectives.

\subsection{The Historical Background of Ceremonial Dance in Ancient Ruins of Southern Isan}

Phimai temple city in Nakhon Ratchasima was built according to the plans of Khmer architects. Phimai is a square walled-city and its name is derived from Vimayapura or Vimaya, which appeared in Khmer inscriptions on the door frames and balconies at the front of the temple. Evidence in the stone inscriptions and artwork indicated that creation of Prasat Hin Phimai began in the period of Emperor Suryavarman I in the $16^{\text {th }}$ century of the Buddhist era on behalf of the Brahman religion. The artistic design is in the Baphuon style, mixed with design elements from Angkor Wat in Cambodia. The temple was adapted to a Buddhist holy place during the reign of Emperor Jayavarman VII, when the influence of Khmer culture declined. After the reign of Emperor Jayavarman VII the Sukhothai Kingdom was established and the importance of Phimai dwindled and disappeared. The Department of Fine Arts announced the registration of Phimai as an ancient ruin and organized its recognition as Phimai Historical Park on the $12^{\text {th }}$ April, 1989 and implemented a thirteen year restoration project. This project was commissioned in the name of Princess Maha Chakri Sirindhorn, who was the chairman of the opening ceremony of the ancient ruin.

From the Thonburi period of Thai history until the Rattanakosin period, Buriram was a single city. This was the case until 1933, when its status was upgraded to a province. Prasat Khao Phanom Rung was originally a Hindu shrine and constructed from the fifteenth to the seventeenth centuries of the Buddhist era. The structure was built to resemble the sacred Mount Kailash, in honour of the deity Shiva. In the eighteenth century of the Buddhist era, emperor Jayavarman VII converted the shrine to a Mahayana Buddhist temple. Prasat Phanom Rung was constructed from pink sandstone and built at the summit of Phanom Rung Mountain, 1,320 feet above sea-level.

At Prasat Sikhoraphum, there are five prang, or Khmer stupas, made from sandstone brick on a single laterite base, which is twenty-five meters wide, twenty-six meters long and one and a half meters high. There are also irrigation ditches along three sides of the structure, all except the Eastern side, which is the entrance to the chief prang. Behind the main entrance is an image of a ten-armed Shiva in a dance posture above his head. Under the arches of the deity's arms are images of Ganesh, Brahma, Vishnu and Parvati. This image comprises part of one of the most beautifully preserved lintels in Thailand. The vertical pillars of the doorframe are adorned with 
images of Apsara carrying lotus leaves and a doorkeeper standing with a staff. The images of Apsara at Prasat Sikhoraphum resemble those found at Angkor Wat, Cambodia and are not found in any other Khmer temples in Thailand. Aside from these features, the remaining aspects of interest concerning the chief central prang and four surrounding prangs at Prasat Sikhoraphum are that they face to the east and each have an eastern staircase. The structures do not have a front porch, are adorned and decorated in sandstone, are covered with many engravings around the lintels and doorframes, there are pillars on the walls and petal decoration, as well as decorative brick architecture. The temple was built in the seventeenth century of the Buddhist era for worship of Shiva and, in the twenty-second century of the Buddhist era, additional restorations were carried out to the Southern side of the temple in the style of Lan Xang art. Additionally, engravings of religious doctrine can also be found on the walls. In 1988, Princess Maha Chakri Sirindhorn invited a teacher from the Chulachomklao Military Academy to study the ancient ruins and a restoration project for Prasat Sikhoraphum was begun to increase its beauty and restore pride in visitors coming to the temple, Sisaket Province, ancient Khmer cultural heritage.

Prasat Sa Kamphaeng Yai has been used by Hinduism and Mahayana Buddhism to enshrine idols. From archaeological excavation by the Department of Fine Arts around the site in 1989, a bronze sculpture was discovered measuring 140 centimeters in height (180 centimeters including the base). Professor Supatdit Disakun identified the sculptures as 'Nantikesuan', or 'Nantisuan'. The special features are that it is a gold-gilded bronze sculpture and that it was probably placed in the front porch of the central section of the complex with the household gods of Shiva. This sculpture is in late Baphuon style and is unique in Thailand. It has not yet been discovered when this temple was built, although there are engravings found in the temple referring to the purchase of the land in dedication to Kamaradeng Chodda Sriphrutthesuan in the year 1042.

The lifestyle of ancient humans was carried out according to feeling and not dressed up or intricate. It was the origin of dance. Singing, dancing and music were the first forms of art. Following these, came drawing, writing and the creation patterns, with instruments and tools to help in the process. Architecture and literature finally appeared last, when humanity was more developed, people knew how to construct residences and there was a greater variety of processes to express feelings beautifully and in ways consistent with the surrounding environment and culture. Dance is an important aspect of culture and necessary for the lifestyle of humans in society, as it enables the expression of feelings and ideas. Dance also allows people to understand one another more easily and is a medium for preserving stories. Dance also provides a response to human needs regarding ceremonies and beliefs by acting as a function of powerful worship and enables people to pray to sacred images or objects for help with their problems and concerns.

\subsection{The Current Conditions of and Problems with Ceremonial Dance in Ancient Ruins of Southern Isan}

Ceremonial dances in the four provinces are for the purposes of worship and apology because the temples are sacred locations of trust in the minds of the residents in the local area. Ceremonial dances to worship the temples are held only once a year, which causes problems with conservation and inheritance in the period after promotion of the event. There are problems with color, sound and lighting as they are not compatible with the forms of the dances. This causes the development of dances in line with modern styles and, therefore, the disappearance of the original art form. There has been adaptation of the dance postures, mixed with modern music, which has seen the fading of the old styles. The fashion and costumes of the performers have also been modernized to make the production seem elaborate and extravagant. The stage production has been adjusted to accommodate the staging and performance area, which has resulted in the loss of identity and performance art in southern Isan. In light of these problems, it is important to conserve and maintain the original art and improve upon the current situation in order to pass knowledge to future generations by transmission and inheritance of ceremonial dance so that it will be preserved forever.

\subsection{A Form of Conservation and Inheritance for Ceremonial Dance in Ancient Ruins of Southern Isan}

Study into a form of conservation and inheritance for ceremonial dance in ancient ruins of southern Isan found that ceremonial dances in ancient ruins in each of the four provinces have their own unique identities in terms of design concept, performance design, beautiful dance postures, symbolic costumes that are part of the identity of the area, local music, melodies and stage productions based on the foundations of conservation and inheritance.

The methods for preservation of the art form are maintenance of that which has already been conserved, conservation of the customs of ceremonial dance, maintenance or improvement of current features so that they have value and promotion of artistic culture by maintaining local wisdom.

Ceremonial dance in ancient ruins may not be in existence for future audiences or students if there is no conservation. Maintenance should concern customs and practices so that future generations can study the performances, music, dance postures, costumes and productions. Data and images must additionally be collected 
into a book for the use of future generations. Current performances should be improved by improving practice of the art and developing skill of the performers in terms of both dancing and music, so to add value to the performances. Improvement of the postures and emotions in the performances will create more aesthetically beautiful performances.

Inheritance is another method to ensure the conservation of ceremonial dance. For this to be achieved, experts must educate the younger generation in the forms, styles and techniques of the performances so that knowledge in the local community is able to continue. By inserting knowledge into the curriculum, the local culture can be altered and knowledge of dance postures and maneuvers, music and costumes can be spread. To inherit in this manner, the transmission of information and those transmitting must have skill and knowledge in the background of the dance. The transmission of information must also be over an extended period of time. Teaching must include information about performance skill and the customs of ceremonial dance. Ultimately, for conservation and inheritance to be lasting, the local community must know about and appreciate the value of its own culture and origins. The conservation project must also be sponsored by external authorities in order for the culture to have a lasting use and for people to see and appreciate the link between the past and the present.

The form of conservation and inheritance for ceremonial dance in ancient ruins of southern Isan is a way of maintaining past culture in order for it to continue as a beautiful identity of the ancient ruins. Each location has made proposals to maintain its ceremonies so that the value of ceremonial dance is visible, the dances are inherited, knowledge is transmitted and their use is continued. Improvement using these methods will ensure that ceremonial dance remains sacred, trusted and valuable to local culture in the future.

\section{Discussion}

The findings of the study of a form of conservation and inheritance for ceremonial dance in ancient ruins of southern Isan can be explained according to the three research objectives.

\subsection{The Historical Background of Ceremonial Dance in Ancient Ruins of Southern Isan}

The beautiful architecture and sculpture at the ancient ruins is engraved with information that tells present students about the history of the temples. These give emphasis to the origins and continued inheritance of the temples, with belief as the medium for trust. The locals place importance upon the ancient ruins, as development and conservation of these historical locations are issues of pride. The long history of the temples shows the irreplaceable value of inheritance of the past with regards feeling and the value of aesthetical beauty or history hidden in the temples. These are the principle thoughts concerning the conservation of ancient ruins and have led to the current protection of various sites. This idea corresponds to the studies of Suriyawut Suksawat (1994: 46-58), which explained that ancient Khmer art was related to religion, influenced by the Indian civilization and developed its own styles and forms. Art historians have studied Khmer art from the evolution of its styles and patterns. The characteristics of the architecture compare to historical events, records and eras found in the Khmer engravings and fit with the styles and age of Khmer art that are agreed upon in current scholarly thought. This corresponds to the theories of Surachet Worakamwichai (1996: 35-68), whose research found that prior to the establishment of the Sukhothai Kingdom in Thailand, the territory was home to a number of established ancient civilizations, some of which were mature, had their own unique identity and had a cultural heritage. This heritage has been passed on until today, importantly the lifestyle, customs and traditions that were similar to those found in India and related to the Brahman or Hindu religions, which subsequently spawned Buddhism in Thailand.

The beliefs of ceremonial dance have derived from the local customs related to respect or prosperity. There are various forms of worship that act as belief, which is in line with the theories and related ideology of Jonathan Turner (1978). Turner analyzed ceremonial symbols found in social activities and concluded that study of symbols must be conducted in their own cultural surroundings in order to see the meaning of the symbols for the members of society. Ceremonies are ways of uniting the members of the community or, at the very least, ceremonies give stability by affirming the structure of existing societies. Ceremonies have a function in strengthening society.

In this study, it was discovered that the postures in ceremonial dance were consistent with the periodic dances of the time and point to the conclusion that they were derived from the dances of India. These Indian dance postures were mixed and compared with original dance postures from the sixth to the eleventh Buddhist eras, so that the final productions contained both derivatives of Indian dance postures and exact copies. The majority of dance postures were related to religion and considered sacred. As a result, the postures were not changed or tampered with very much until the eleventh and twelfth Buddhist centuries, when the influence of Thai dance became more evident. This shows that Thai dance designers recreated the Indian versions to conform to Thai 
identity, while retaining the style of the 108 dancing postures of Shiva. This information corresponds to the study of Pitsanu Khempila (1996, p.128), which found that dancing postures in Khmer-style sculptures of Shiva in northeast Thailand are similar to the dancing postures used in Ra Bam Lopburi, Lopburi Province. The set of postures in Ra Bam Lopburi is an integration of Lopburi folk dance with the postures of Shiva, and so creates a new identity of folk dance culture, while conserving the ancient dance postures carved on the walls of prasat in Lopburi and the provinces of Northeastern Thailand.

\subsection{The Current Conditions of and Problems with Ceremonial Dance in Ancient Ruins of Southern Isan}

Ceremonial dance in the ancient ruins of southern Isan is confronted with problems of changing culture and styles. The dissemination of culture is a factor that prompts lifestyle change in every aspect as the methods of one society influence another. This is consistent with the theories of Yot Santasombat (1997: 25), who stated that the origins of a civilization disseminate culture into society and cross-cultural trade and business cause the original culture to influence further regions; this is a cultural cycle. The majority of humans in various societies do not have creative ideas, causing them to take and borrow aspects of other cultures. This enables present students to identify collections of similar cultures in the same geographical area. There are four methods of identifying cultural dissemination: a) when another culture has been integrated into the existing culture; b) when a culture has been interpreted from descendents; c) when archaeological excavation has led to concrete evidence about past culture; d) when evolution of a culture has led to specific growth and progress.

Searching for appropriate ways to conserve and perpetuate worship dancing performance is an important difficulty. This is consistent with the theories of Chommanak Sophon (1988: 45-49). Sophon wrote that there are two educational forms of Thai dramatic performing studies. The first is a form of informal education, while the second is education managed by private or state schools, where the curriculums are firmly set. There are three ages of Thai dramatic performing studies. The first age, until 1910, was traditional Thai dramatic performing studies at royal schools. The studies were reserved for ladies in the royal palace only, who were instructed by royal dancing experts. The second age, from 1910 until 1935 was traditional Thai dramatic performing studies by schools using the old curriculum. The third age, from 1936, is traditional Thai dramatic performing studies by educational institutes instructing both Thai dramatic performance and international dramatic performing arts, where learners can select to learn an artist curriculum or a teacher curriculum. The knowledge and understanding of ceremonial dancing concepts is necessary for setting the forms of conservation and inheritance.

\subsection{A Form of Conservation and Inheritance for Ceremonial Dance in Ancient Ruins of Southern Isan}

Humans create art either through adaptation from nature for the purposes of beauty and emotion to convey a variety of different meanings, or using their own imagination to clear the mind. This shows the value of expressing beauty in a variety of forms or replicating the impressive beautiful intricacies of nature.

The importance of entertainment, popularity, intelligent concepts and aesthetics is agreed upon by Prachit Sakunapat (2005, p.192). Sakunapat found that aesthetics is a branch of philosophy concerning the beauty of art and harmony of things in nature or literary art. Beauty is the relationship between material and the mind but, in order to understand the beauty of an object, it is necessary to have training in the appreciation of the value of beauty; only then will full appreciation of and fascination with beauty become evident. The principles of beauty are the value and the everyday importance to humanity, which people will realize, understand and feel, along with the experience of each individual. These are able to affect the behavior of humans in accordance with the time period and surrounding social environment. Culture, aesthetics and beauty are such a wonderful mixture that imitation in suitable proportions retains visible purity and gives sufficient levels of satisfaction and enjoyment. The levels of beauty of the artistic product depend on the skill of the artist. This artistic skill has had an effect on the ceremonial dances as the postures used are derived from the artwork in the temples, meaning that the skill of the original artist is reflected in the dance. This is in line with the views of Surapon Wirutrak (2006: 225-256), which explained that the concepts, forms and creation of an individual or ensemble dance are based upon improvements of past results. Contemporary dance includes the philosophies, content, meaning, dance postures, dance arrangements, music, costumes, background and other props that are used in the production. The important features of a complete performance are: a) vision; b) defined principles; c) data collection; d) defined boundaries; e) defined form; f) defined components; g) dance style. Each aspect ensures that the art is improved.

Ceremonial dance in any location in any language respects the rituals of the time. The dance is dependent upon the music, singing and acting, which takes different forms and names in different locations. The performance is conceived in its beauty and intricacy by humans to entertain and evoke emotion. The feeling of the audience is in accordance with the performance and is a part of artistic culture, including painting, architecture, literature, music and dance. The form of the performance is different from performances in other countries, as it is a 
distinct, delicate art with beautiful rhythms and postures. Costumes currently used in ceremonial dance in ancient ruins have conserved and inherited the original traditions and are part of the cultural heritage from the past. This is a cultural heritage that creates the national identity of which Thai nationals are proud.

It is important to conserve and maintain ceremonial dance and its customs in order to add value. The artistic culture can be supported by maintenance of local wisdom. If there is no conservation, maintenance or improvement then the culture will have no value. This is in correspondence to the research of Supattra Supap (1985: 12), which concluded that conservation, compilation and retention of resources is vital to prevent deficiencies in the future.

Conservation and inheritance of ceremonial dance in the ancient ruins of southern Isan should begin with the collaboration of all sectors of society. The key concept of conservation and inheritance of ceremonial dance performances is to conserve value, promote awareness and appreciation of antiquity and develop it in an appropriate way. This is consistent with the research results of the Department of General Education (1998: 12), which suggest that for Thai culture to retain its identity over time, it does not only depend on the Ministry of Culture but also on the Thai people. The Ministry of Culture must merely act as a mirror to reflect cultural changes appearing both domestically and internationally. As these changes affect Thai culture, the people should adapt themselves and only select the strengths of other cultures for use in Thailand. Ceremonial dancing knowledge should be written in school curriculums, in order to transmit the knowledge of dancing performance and the background of performance. Promoting ceremonial dance performances to the public requires the close cooperation of all sectors of society. The Ministry of Culture must designate a supporting budget for all concerned promotions, all members of the private sector must participate in all promotion activities and performers must perform to the best of their abilities at every ceremony.

Improvement of the current situation and changes to society will make alterations fast but it is important to ensure the value and benefits of the performance remain. There should be training to improve the skill of the musicians and dancers in order to add value to the artistic culture of each location. The postures and emotions of the performance must also be improved to generate higher quality aesthetics in the performance. This agrees with the study of Prathep Weti (1993: 83-130) which found that there must be development and adaptation as the Thai culture of the local area has been neglected. In order for society to be accurately developed, it is necessary to develop in harmony with culture. For there to be a harmonious connection, the development must use culture as its tool, which will also cause the culture to develop in turn.

Inheritance is another way to ensure the existence of ceremonial dance through the transmission of knowledge from experts to students. The experts must have skill in passing on their knowledge to students, as well as personal performance skill and understanding of the customs and traditions. This corresponds to the study of Boonsong Chaising-Kananon (1989: 102), which found that the essential factors in increasing the importance of the performers are their own ability and their portrayal of the performance in such a way that conveys the appreciation of beauty, skill and knowledge. The artist must use creative thought and imagination, along with valuable aesthetics.

For lasting use of the performing art there ought to be care and maintenance of culture. The locals must also realize the importance of the performance as part of their own identity. This is in agreement with the findings of Bunditpatanasilpa Institute (2007: 1-5), which stated that art culture at both the local and national levels must provide instruction, performance, research and academic service.

Publicity ought to make use of the local cultural identity to present the national artistic culture, so as to generate stability between the two, add value to the local culture and highlight the relationship between the past and present. This corresponds to the research of Sutthiwong Pongpaiboon (1988: 58), which argued that the important aim of promotion and publicity of local culture was to generate short and long term cooperation and unity among the people in order to uphold their local culture and pass it on to future generations. This also agrees with the investigation of Yot Santasombat (1997: 25), which explained that the dissemination of culture resulted in the absorption of that culture into the identities of other communities and, ultimately, other nations.

From this study, the researchers conclude that the form of conservation and inheritance for ceremonial dance in ancient ruins of southern Isan must have continual sponsorship from various institutions. This will maintain ceremonial dance in ancient ruins in its original form by collecting data as educational materials and enable transmission of the customs and culture so that ceremonial dance may last in the future. Another method is by improving publicity of the local identity, so that it has extra benefit and a higher value. 


\section{References}

Bunditpatanasilpa Institute. (2009, July 9). Royal Act of Bunditpatanasilpa Institute 2007. In Government Gazette, 124(32).

Chaising-Kananon, B. (1989). Characteristics of art work. Bangkok: Chulalongkorn University.

Department of General Education. (1998). The constitution of the Thai Kingdom B.E. 2540. Bangkok: Kansatsana Printing House.

Khempila, P. (1996). A study of dancing postures from the sculptures of Shiva Nataraja in Khmer style art found in Northeastern Thailand and the creation of dancing postures of Ra Bam Lopburi. Maha Sarakham: Mahasarakham University.

Lengbracha, N. (1990). Foundations of Thai culture. Bangkok: Chulalongkorn University.

Pongpaiboon, S. (1988). Viewpoint of promotion and publicity of local culture. In Methods for promoting and publicizing local Thai culture. Bangkok: Kurusapha Ladprao.

Sakunapat, P. (2005). Thai art and culture. Bangkok: Saengdao.

Santasombat, Y. (1997). Research into the methods of development for increasing the potential of cultural tourism villages. Bangkok: The Tourism Authority of Thailand.

Sophon, C. (1988). The development of Thai dramatic performance studies in Thailand. Bangkok: Chulalongkorn University.

Suksawat, S. (1994). A study of Khmer lintels in fine arts division 6 Phimai. Bangkok: Silpakorn University.

Sunthranon, R. (2005). Thai dramatic arts curriculum. Bangkok: Aksorn Charoenthat.

Supap, S. (1985). Thai society and culture. Bangkok: Thai Wattanapanich.

Tourism Authority of Thailand. (1999). Nakhon Ratchasima. Bangkok: Bopit Publishers.

Tourism Authority of Thailand. (2011). Marketing plan of tourism 2012. Bangkok: Borphit Kanphim.

Turner, J. (1978). The structure of sociological theory. Homewood: The Dorsey Press.

Weti, P. (1993). A historical documentary of Phra Wihan Mountain. Bangkok: National Research Council.

Wirutrak, S. (2006). Thai dramatic art in the reign of King Rama IX. Bangkok: Chulalongkorn University.

Worakamwichai, S. (1996). History of Southern Isan. Bangkok: Mueang Boran.

\section{Copyrights}

Copyright for this article is retained by the author(s), with first publication rights granted to the journal.

This is an open-access article distributed under the terms and conditions of the Creative Commons Attribution license (http://creativecommons.org/licenses/by/3.0/). 